\title{
OCCURRENCE OF THE FUNGI FROM THE GENUS AMPELOMYCES - HYPERPARASITES OF POWDERY MILDEWS (ERYSIPHALES) INFESTING TREES AND BUSHES IN THE MUNICIPAL ENVIRONMENT
}

\author{
Ewa Sucharzewska, Maria Dynowska, Aneta Bożena Kempa \\ Department of Mycology, University of Warmia and Mazury in Olsztyn \\ Oczapowskiego 1A,10-719 Olsztyn-Kortowo, Poland \\ e-mail: ewko@uwm.edu.pl
}

(Received: March 23, 2010. Accepted: July 19, 2010)

\begin{abstract}
The studies refer to the phenomenon of hyperparasitism in the municipal environment. The paper presents the occurrence of fungi of the genus Ampelomyces on Erysiphales - important group of phytopathogenic fungi. For the first time in Poland analyzed degree of infestation of Erysiphales mycelium by Ampelomyces and effect of the hyperparsites on the degree of infestation plants by Erysiphales. The high participation of the Ampelomyces was noted in each year of the study. Substantial differences were noted in the occurrence of Ampelomyces depending on the developmental stage of the host fungi and considerable differences in the prevalence of the hyperparasites on particular Erysiphales species. In all cases examined, the mean index of infestation of host plants by Erysiphales was higher than the mean degree of infestation of powdery mildew mycelium by Ampelomyces. The results indicate that under natural conditions they do not play any significant role in the reduction of the degree of infestation of host plants by Erysiphales and do not disturb drastically their life cycle.
\end{abstract}

KEY WORDS: Ampelomyces, Erysiphales, hyperparasites, municipal environment.

\section{INTRODUCTION}

Fungi from the genus Ampelomyces (Ces. ex Schlecht.) are hyperparasites colonizing mycelium, conidial spores and young fruiting bodies of powdery mildews (Erysiphales) - obligate patogens of plants (Kiss et al. 2004). Ampelomyces are widespread worldwide, they are thermophilic organisms, adapting well to various climatic conditions (Sundheim 1982). They belong to the class of Coelomycetes, Anamorfic fungi - formerly Deuteromycota (Sutton 1980; Kirk et al. 2001).

In literature there have been described ca. 46 species of the genus Ampelomyces, infesting different species of powdery mildew. The most up to day genetic researches of the ribosomal DNA (rDNA) of the ITS region confirm the existence of more that one species of the genus Ampelomyces (Kiss 1997; Kiss, Nakasone 1998; Kiss, Vajna 1995; Liang et al. 2007; Szentivànyi et al. 2005). In view of those investigations, the application of dual nomenclature Ampelomyces quisqualis - for the description of fungi of that genus seems to be incorrect (Kiss et al. 2004).

Investigations referring to Ampelomyces are mainly focused on their utilization in a biological fight against powdery mildews that induce diseases of economicallyimportant plants (Falk et al. 1995; Gu 1998; Kiss 2003;
Kiss at al. 2004). In turn, still little attention is paid to the ecology of those parasites, their occurrence and effect on the development of Erysiphales in the natural environment (Kiss et al. 2004).

In Poland the Ampelomyces have been noted onto 44 species of Erysiphales belonging to six genera: Erysiphe, Microsphaera, Podosphaera, Sphaerotheca, Uncinula and Oidium (Mułenko et al. 2008). Those works document only sporadic presence of that mycoparasites without assays of the infestation degree of host mycelium nor the infested morphological structures. Those investigations were usually conducted in plants communities, characterized by a low degree of anthropopression. In contrast, there are sparse works referring to the presence of Ampelomyces on Erysiphales in the municipal environment, which report on the high prevalence of that mycoparasites (Madej and Antoszczyczyn 1965; Sucharzewska and Dynowska 2002). In Polish literature also is lack of information about degree of infestation of powdery mildew by Ampelomyces and their effect on the development of powdery mildews.

The presented research was aimed at evaluating the prevalence of fungi of the genus Ampelomyces and at determining the extent of mycelium infestation by those mycoparasites of powdery mildew species, infesting trees and bushes in the municipal environment. 


\section{MATERIAL AND METHODS}

The research was conducted on the area of the city of Olsztyn during two vegetative seasons of 2005/2006. The experimental material were leaves of trees and bushes infested with Erysiphales. Ten leaves collected at random from each infested host plant served as one sample.

1. Each sample was determined for the extent of infestation of the host by powdery mildews, using a five-degree scale according to Mc Kinney's formula (Dynowska 1994):

$$
\mathrm{R}=\frac{\Sigma(\mathrm{a} \times \mathrm{b}) \times 100 \%}{\mathrm{~N} \times 4}
$$

where:

$\mathbf{R}$ - an index of plants infestation by Erysiphales expressed in per cents (\%);

$\Sigma(\mathbf{a} \times \mathbf{b}) \times \mathbf{1 0 0 \%}$ - the sum of products obtained by multiplying the number of plant organs examined (a) by the degree of infestation (b);

$\mathbf{N}$ - the total number of examined plants (relatively of leaves or fruits);

4 - the highest degree of infestation in the five-degree scale $(0$ - lack of infestation; 1 - up to $10 \% ; 2-11-25 \%$; 3 $-26-50 \% ; 4-51-100 \%$ of infestation).

Species of Erysiphales were determined by means of keys by Braun (1987) and Sałata (1985). Nomenclature was adopted after Braun and Takamatsu (2000) and Braun et al. (2003). The host plants were determined according to Rutkowski (1998) and Bugała (1991). Nomenclature was adopted after Mirek et al. (1995).

2. Analyses were conducted for the presence of the hyperparasites - Ampelomyces on the mycelium of powdery mildews and for its effect on the development of the fungi examined.

- each sample was determined for the extent of infestation of powdery mildews mycelium with Ampelomyces, using the Mc Kinney's formula with appropriate modifications:

$$
\mathrm{R}_{\text {Ampelomyces }}=\frac{\Sigma(\mathrm{c} \times \mathrm{d}) \times 100 \%}{\mathrm{~N} \times 4}
$$

where:

$\mathbf{R}_{\text {Ampelomyces }}$ - an index of Erysiphales mycelium infestation by Ampelomyces expressed in per cents (\%);

$\Sigma(\mathbf{c} \times \mathbf{d}) \times \mathbf{1 0 0 \%}$ - the sum of products obtained by multiplying the number of collected plant organs infested with powdery mildew (c) by a given degree of infestation (d);

$\mathbf{N}$ - the total number of organs infested with Erysiphales; 4 - the highest degree in the five-degree scale.

The final values of infestation indices (R), taken into account in the analysis of results, were calculated based on an arithmetic mean for each fungal species and described as a mean index of infestation.

\section{RESULTS}

Over the two-year study, a total of 305 samples with powdery mildews were collected, including 186 in the year 2005 and 119 in the year 2006. The presence of Ampelomyces was detected on 111 samples, which constitutes $36 \%$ of the samples examined (Table 1). Hyperparasites were noted in each year of the study. No difference was observed in the percentage contribution of the samples with Ampelomyces in particular analytical seasons (38\% in $2005,39 \%$ in 2006).

Over the entire experimental period, there were collected 14 species of fungi of the order Erysiphales at the sexual stage on 20 host plants as well as 12 species at the asexual stage (Oidium) on 14 host plants (Table 1).

Substantial differences were noted in the occurrence of Ampelomyces depending on the developmental stage of the host fungi. Mycoparasites were detected onto 4 out of 12 species of Erysiphales at the asexual stage (Oidium) which constitutes $33 \%$ as well as onto 9 out of 14 species of powdery mildew being at the sexual stage, which constitutes $64 \%$ (Table 2).

In addition, observations made in the study enabled determining considerable differences in the prevalence of Ampelomyces on particular Erysiphales species at the sexual stage. The highest number of the samples with mycoparasites was noted in the case of Erysiphe vanbruntiana var. sambuci-racemosae ( $92 \%$ of the samples), E. flexuosa $(83 \%)$, and E. berberidis (69\%) - (Fig. 1). The high prevalence of Ampelomyces was also reported in the samples with Phyllactinia fraxini (56\%) and E. palczewskii (55\%). In contrast, the lowest prevalence of Ampelomyces was observed in the samples with P. guttata (7\%). In turn, the Ampelomyces were not detected on five Erysiphales species at the sexual stage: E. adunca, E. alphitoides, E. tortilis, E. trifolii and Sawadaea bicornis (Fig. 1).

The analysis of an infestation degree of mycelium of Erysiphales at the sexual stage by Ampelomyces, demonstrated a high mean index of infestation in the case of two species of powdery mildew: E. berberidis on Mahonia aquifolium (83\%) and on Berberis vulgaris (59\%), and $E$. vanbruntiana var. sambuci-racemosae on Sambucus racemosa (56\%) (Fig. 2). The lowest mean degree of powdery mildews mycelium infestation by Ampelomyces was reported for: P. guttata on Betula pendula (6\%) and for $S$. tulasnei on Acer ginnala (3\%) (Fig. 2).

A considerably lower degree of Erysiphales mycelium infestation by Ampelomyces was determined at the asexual stage. A high infestation index was noted only at the conidial stage (Oidium) on A. platanoides (51\%), whereas in the other Erysiphales species being at the asexual stage, the infestation index accounted for $<13 \%$.

In all cases examined, the mean index of infestation of host plants by Erysiphales was higher than the mean degree of infestation of powdery mildew mycelium by Ampelomyces (Fig. 2).

\section{DISCUSSION}

Hyperparasitism is one of the mechanisms of an antagonistic action, in which one fungus absorbs nutrients from another parasitic fungus being its host (Jeffries 1995). 
TABLE 1. The list of Erysiphales species and host plants. The number of samples with powdery mildew infected and uninfected by Ampelomyces in the study years.

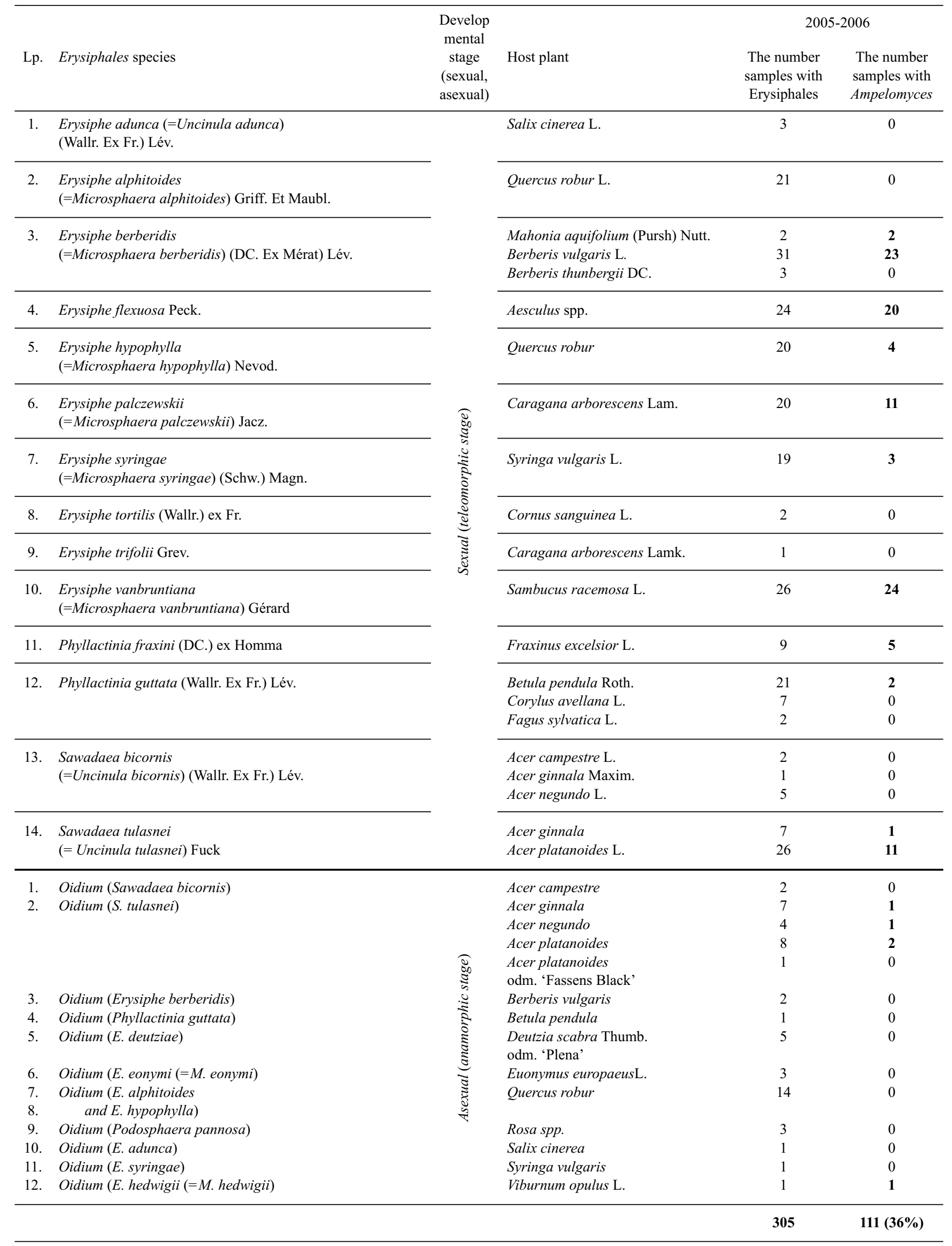

There are known around forty species of fungi claimed to be natural antagonists of Erysiphales (Kiss 2003). One of the best known hyperparasites of powdery mildews are fungi of the genus Ampelomyces. Investigations focusing 
TABLE 2. Percentage contribution of samples with powdery mildew infected by Ampelomyces in different stage of development.

\begin{tabular}{lcc}
\hline Developmental stage & $\begin{array}{c}\text { Samples } \\
\text { without Ampelomyces }\end{array}$ & $\begin{array}{c}\text { Samples } \\
\text { with Ampelomyces }\end{array}$ \\
\hline Asexual (Oidium) & $67 \%$ & $\mathbf{3 3 \%}$ \\
Sexual & $36 \%$ & $\mathbf{6 4 \%}$ \\
\hline
\end{tabular}

on those mycoparasites enabled explicit recognition of their biology and life cycle. But still, little attention has been devoted to the ecology of the Ampelomyces and their role in the natural environment.

In Poland, in recent years several references report on the occurrence of Ampelomyces on powdery mildews, including works of among others: Adamska et al. (1999) on the area of the Słowiński National Park, Czerniawska (2001a, b), Czerniawska et al. (2000) on the area of Drawski National Park and Mułenko, Wojdyło (2002) on the south of Poland or Ruszkiewicz-Michalska (2006) from the area of the Częstochowska Upland. Those investigations were usually conducted in phytocenoses and ecosystems interesting from the floristic and phytosociological point of view and characterized by a low degree of anthropopression. Often, these are protected areas with conditions similar to the natural ones, including national parks or reserves. Those works document only sporadic presence of that hyperparasites. This is most likely due to the fact that those work are inventory in character and involve the determination of species of powdery mildew and only occasional notice of their presence onto Ampelomyces, without assays of the infestation degree of host mycelium nor the infested morphological structures. In contrast, there are sparse works referring to the presence of Ampelomyces on Ery-

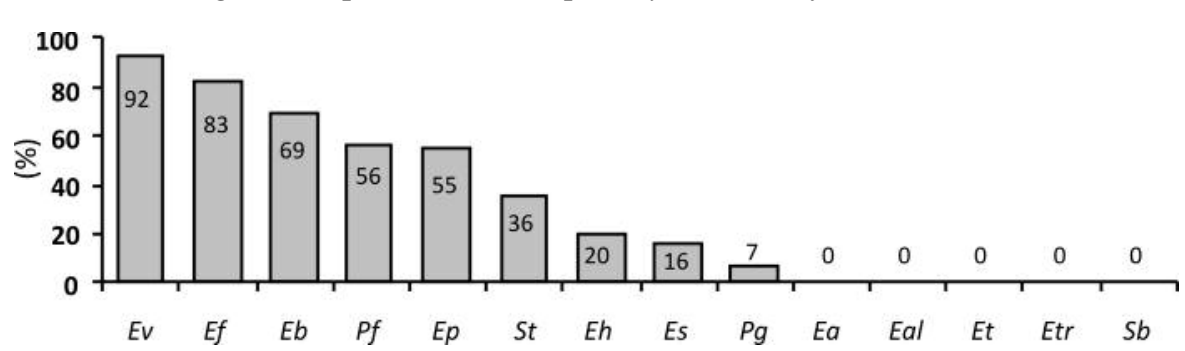

$\boldsymbol{E} \boldsymbol{a}-$ Erysiphe adunca; $\boldsymbol{E a l}-$ E. alphitoides; $\boldsymbol{E \boldsymbol { b }}-$ E. berberidis; $\boldsymbol{E \boldsymbol { f }}-$ E. flexuosa; Eh - E. hypophylla; $\boldsymbol{E p}-$ E. palczewskii; Es - E. syringae, Et - E. tortilis; Etr - E. trifolii; $\boldsymbol{E} \boldsymbol{v}-$ E. vanbruntiana var. sambuci-racemosae; Pf-Phyllactinia fraxini; Pg - P. guttata; $\boldsymbol{S t}$-Sawadaea tulasnei; $\boldsymbol{S b}$-S. bicornis.

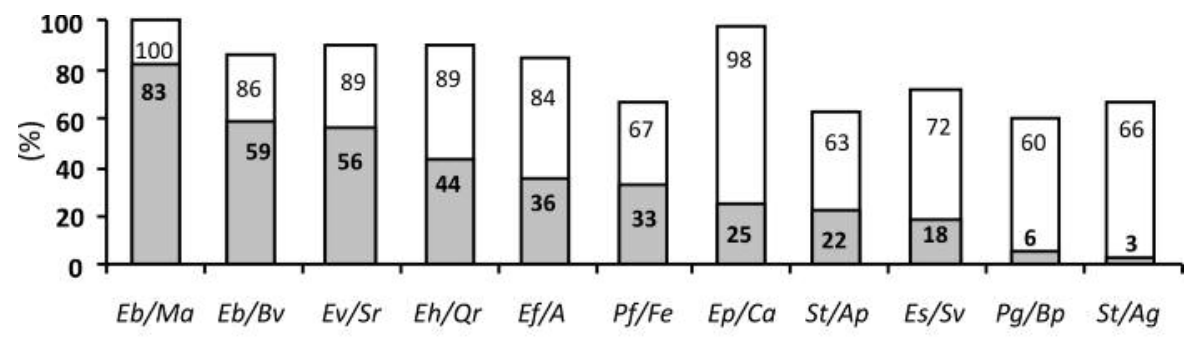

mean index of infestation of host plants by Erysiphales mean index of infestation Erysiphales by Ampelomyces

$\boldsymbol{E} \boldsymbol{b} / \boldsymbol{M a}-$ E. berberidis on M. aquifolium; $\boldsymbol{E b} / \boldsymbol{B} \boldsymbol{v}-$ E. berberidis on B. vulgaris; $\boldsymbol{E} \boldsymbol{f} / \boldsymbol{A}-$ E. flexuosa on Aesculus spp.; Eh/Qr - E. hypophylla on $Q$. robur; $\boldsymbol{E p} / \boldsymbol{C a}-E$. palczewskii on C. arborescens; $\boldsymbol{E} \mathbf{s} / \boldsymbol{S} \boldsymbol{v}-$ E. syringae on $S$. vulgaris; $\boldsymbol{E v} / \mathbf{S r}-$ E. vanbruntiana var. sambuci-racemosae on $S$. racemosa; Pf/Fe $-P$. fraxini on F. excelsior; $\boldsymbol{P g} / \boldsymbol{B p}-P$. guttata on B. pendula; $\boldsymbol{S t / A p}-S$. tulasnei on A. platanoides; $\boldsymbol{S t / A g}-$ S. tulasnei on A. ginnala. siphales in the municipal environment, which report on the high prevalence of that hyperparasites (Madej and Antoszczyczyn 1965; Sucharzewska and Dynowska 2002).

The continued own study confirmed the high prevalence species being at the sexual stage and - to a lesser extent the asexual stage. In addition, analyses showed consid(92\%), E. flexuosa (83\%) and $E$. berberidis $(69 \%)$ Ruszkiewicz-Michalska (2006), in study conducted on the area of the Czestochowska Upland, did not detect the presAmpelomyces on other powdery mildews: $E$. hypophylla, E. palczewskii, E. syringae and P. guttata, which in our orest and turf communities that are not exposed to strong thropopression. In turn, Majewski (1971) suggests, that cosociological analyses in the Białowieski National despite intensive searches.

Puzzling is then the lack of reports on the presence of Ampelomyces on Erysiphales in Polish and foreign works conducted on areas being under the influence of anthropopression (Feige and Ale-Agha 1999; Mikołajska and
Fig. 1. Percentage contribution of samples with the analyzed species of Erysiphales at sexual stage infected by Ampelomyces.
Fig. 2. Mean infestation degree of host plants by Erysiphales and mean infestation degree of species of Erysiphales at sexual stage by Ampelomyces 
Dynowska 1982; Kalinowska-Kucharska and Kadłubowska 1993; Hołownia and Kostrzewska 1991).

The reported study also presents a comprehensive analysis of the extent of infestation of mycelium of the analyzed powdery mildew species by the hyperparasites. This is the first Polish study addressing that issue. In the available world literature, alike investigations - namely the evaluation of the infestation degree of mycelium of selected species of powdery mildews - were carried out by Kiss (1998) and Rankovič (1997). They reported a high percentage of E. berberidis mycelium infestation by Ampelomyces. Our study confirmed that this species of powdery mildew (along with E. vanbruntiana and E. flexuosa) is the most frequently and to the greatest extent infested by the hyperparasites analyzed. Kiss (1998) did not detect the presence of Ampelomyces on mycelium of three Erysiphales species: E. alphitoides, E. syringae and S. bicornis. In turn, in our study the hyperparasites were not observed on five species of powdery mildews, i.e.: E. adunca, $E$. alphitoides, E. tortilis, E. trifolii and S. bicornis. On that last species the hyperparasites belonging to the genus Ampelomyces were noted by Mułenko and Wojdyła (2002), and on E. alphitoides by Ruszkiewicz - Michalska (2006). In the case of E. adunca, E. tortilis and E. trifolii, the lack of those hyperparasites may result from a too low number of samples collected for analyses. In turn, on the last two species, the Ampelomyces were noted by Rankovič (1997). The presence of the hyperparasites on E. syringae infesting Syringa vulgaris, has been reported for the first time ever on that host fungi. The differences in the preference of the host fungi by hyperparasites from the genus Ampelomyces are likely to result from the existence of different species, confirmed by genetic research of rDNA of the ITS region (Kiss 1997; Kiss and Nakasone 1998; Kiss and Vajna 1995; Liang et al. 2007; Szentivànyi et al. 2005).

Literature reports on a considerable role of Ampelomyces in growth inhibition of Erysiphales (Falk et al. 1995; Füzi 2003; Madej and Antoszczyszyn 1965). In contrast, our previous investigations (Sucharzewska and Dynowska 2002) indicate that this hyperparasites did not reduce considerably the degree of infestation of a few species of powdery mildew. This has also been confirmed in a work by Kiss (1997), who was analysing the presence of Ampelomyces on powdery mildews infesting plants of the family Gramineae. He concluded on the lack of sound evidence of the effect of that hyperparasites on the impairment of sporulation of the mycelium of Blumeria graminis - a dangerous parasite of cereals. In the continued own study, in all the observed cases the mean degree of infestation of the host plants by powdery mildews was always higher than the mean degree of infestation of Erysiphales mycelium by the hyperparasites. This results from the fact that over the entire analytical period, the Ampelomyces were noted mainly at the end of the life cycle of powdery mildews, on mycelium producing fruiting bodies and - to a lesser extent - on the conidial stage. Results obtained in the reported study correspond with findings of other authors who claim that Ampelomyces colonizes only ageing colonies of powdery mildews, being at the teleomorphic stage in which the degree of plants infestation exceeds 60\% (Füzi 2003; Gadoury and Pearson 1998; Gadoury et al. 1991).

In summary it may be concluded that the reported study proves that fungi of the genus Ampelomyces find very good conditions for the development on the mycelium of powdery mildews, infesting trees and bushes in the environment strongly transformed by man. They may, thus, be recognized as "urbanophilic" species. The high prevalence of the hyperparasites of that genus at, simultaneously, a high prevalence of powdery mildews suggests that under natural conditions they do not play any significant role in the reduction of the degree of infestation of host plants by Erysiphales and do not disturb drastically their life cycle.

\section{LITERATURE CITED}

ADAMSKA I., MADEJ T., CZERNIAWSKA B.J. BŁASZKOWSKI. 1999. Parasitic and saprotrophic fungi from Słowiński National Park. Acta Mycol. 34 (1): 97-103.

BRAUN U. 1987. A monograph of the Erysiphales (powdery mildews). Nova Hedw. 89: 1-700.

BRAUN U., CUNNINGTON J.H., BRIELMAIER-LIEBETANZ U., ALE-AGHA N., HELUTA V. 2003. Miscellaneous notes on some powdery mildew fungi. Schlechtendalia 10: 91-95.

BRAUN U., TAKAMATSU S. 2000. Phylogeny of Erysiphe, Microsphaera, Uncinula (Erysipheae) and Cystotheca, Podosphaera, Sphaerotheca (Cystotheceae) inferred from rDNA ITS sequences - some taxonomic consequences. Schlechtendalia 4: 1-33.

BUGAŁA W. 1991. Drzewa i krzewy dla terenów zieleni. Wyd. II. PWRiL. Warszawa, pp. 1-594.

CZERNIAWSKA B. 2001 a. Erysiphales of the Drawski Landscape Park (NW Poland). Acta Mycol. 36 (1): 67-80.

CZERNIAWSKA B. 2001b. Studies on the biology and occurrence of Ampelomyces quisqualis in the Drawski Landscape Park (NW Poland). Acta Mycol. 36 (2): 191-201.

CZERNIAWSKA B., MADEJ T., ADAMSKA I., BŁASZKOWSKI J., RADYCH M. 2000. Erysiphales and their hyperparasite, Ampelomyce quisqualis, of the Drawsko Landscape Park, Poland. Acta Mycol. 35 (1): 79-84.

DYNOWSKA 1994. A comparison of urban and suburban occurrence of Erysiphales with special emphasis on degree of host infection. Acta Soc. Bot. Pol. 63 (3-4): 341-344.

FALK S.P., GADOURY D.M., PEARSON R.C., SEEM R.C. 1995. Partial control of grape powdery mildew by the mycoparasite Ampelomyces quisqualis. Plant Disease. 79: 483-490.

FEIGE G.B., ALE-AGHA N. 1999. Observations of the occurrence of some Erysiphales in the Ruhr area. Med. Fac. Landbouww. Univ. Gent 64: 593-606.

FÜZI I. 2003. Natural parasitism of Uncinula negator cleistothecia by Ampelomyces hyperparasites in the South-Western vineyards of Hungary. Acta Phytopath. et Entom. Hungarica. 38: 53-60.

GADOURY D.M., PEARSON R.C. 1998. Initiation, development, dispersal and survival of cleistothecia of Uncinula necator in New York vincyards. Phytopathology 78: 1413-1421.

GADOURY D.M., PEARSON R.C., SEEM R.C. 1991. Reduction of the incidence and severity of grape powdery mildew by Ampelomyces quisqualis. Phytopathology 81: 122.

GU Y.H. 1998. Liquid culture of Ampelomyces quisqualis, a mycoparasite for biological control of powdery mildews. Ann. Phytopathol. Soc. Jpn. 64: 458-461.

HOŁOWNIA I., KOSTRZEWSKA A. 1991. Obserwacje nad grzybami pasożytniczymi Torunia. Acta Universitetis Nicolai Copernici. Biologia 36 (74): 155-163. (in Polish)

JEFFERIES P. 1995. Biology and ecology of mycoparasitism. Can. J. Bot. 73 (Suppl. 1): 1284-1290.

KALINOWSKA-KUCHARSKA E., KADŁUBOWSKA J.Z. 1993. Grzyby rodziny Erysiphaceae Polski Centralnej. Spraw. z Czynn. i Pos. Nauk. 47: 275-279. (in Polish)

KIRK P.M., CANNON P.F., DAVID J.C., STALPERS J.A. 2001. Ainsworth and Bisby's dictionary of the fungi. Ed. IX. CABI Bioscience, CAB. pp. 1-616. 
KISS L. 1997. Graminicolous powdery mildew fungi as new hosts of Ampelomyces quisqualis. Can. J. Bot. 75: 680-683.

KISS L. 1998. Natural occurrence of ampelomyces intracellular mycoparasites in mycelia of powdery mildew fungi. New Phytol. 140: 709-714.

KISS L. 2003. A review of fungal antagonists of powdery mildews and their potential as biocontrol agents. Pest Manag. Sci. 59: 475-483.

KISS L., NAKASONE K.K. 1998. Ribosomal DNA internal transcribed spacer sequences do not support the species status of Ampelomyces quisqualis, a hyperparasite of powdery mildew fungi. Current Genetics 33 (5): 362-367.

KISS L., RUSSELL J. C., SZENTIVANYI O., XU X., JEFFRIES P. 2004. Biology and biocontrol potencial of Ampelomyces quisqualis, natural antagonists of powdery mildew fungi. Biocontrol Science \& Technology. 14 (7): 635-651.

KISS L., VAJNA L. 1995. New approaches in the study of the genus Ampelomyces quisqualis, hyperparasite of powdery mildew fungi. In: M. Mańka (ed.), Environmental biotic factors in integrated plant disease control: 301-304.

LIANG CH., YANG J., KOVÁCS M.G., SZENTIVÁNYI O., LI B., XU X.M., KISS L. 2007. Genetic diversity of Ampelomyces mycoparasites isolated from different powdery mildew species in China inferred from analyses of rDNA ITS sequences. Fungal Diversity 24: 225-240.

MADEJ T., ANTOSZCZYSZYN S. 1965. Ampelomyces quisqualis ces. (Cicinnobolus cesatii de Bary) w Szczecinie. Biuletyn Instytutu Ochrony Roślin. 30: 65-73.

MAJEWSKI T. 1971. Grzyby pasożytnicze Białowieskiego Parku Narodowego na tle mikoflory Polski (Perenosporales, Erysiphales, Uredinales, Ustilaginales). Acta Mycol. 7: 299-388.

MIKOŁAJSKA J., DYNOWSKA M. 1982. Materiały do znajomości grzybów pasożytniczych Pojezierza Mazurskiego. I. Erysiphales. Acta Mycol. 18 (2): 213-222.
MIREK Z., PIEKOŚ-MIRKOWA H., ZAJĄC A., ZAJĄC M. 1995. Vascular plants of Poland. A Checklist. Polish Botanical Studies. Guidebook Series No.15, PAN, Kraków, pp. 303.

MUŁENKO W., MAJEWSKI T., RUSZKIEWICZ-MICHALSKA M. 2008. A Preliminary Checklist of Micromycetes in Poland. Wstępna lista grzybów mikroskopijnych Polski. Polish Academy of Sciences. Kraków, pp. 1-752.

MUŁENKO W., WOJDYŁO B. 2002. Mikroskopijne grzyby pasożytnicze drzew i krzewów Arboretum Bolestraszyce. Arboretum Bolestraszyce. 9: 5-14. (in Polish)

RANKOVIČ B. 1997. Hyperparasites of the genus Ampelomyces on powdery mildew fungi in Serbia. Mycopathologia 139:157-164.

RUSZKIEWICZ-MICHALSKA M. 2006. Mikroskopijne grzyby pasożytnicze w zbiorowiskach roślinnych Wyżyny Częstochowskiej. Monographiae Bot. Vol. 96. (in Polish)

RUTKOWSKI L. 1998. Klucz do oznaczania roślin naczyniowych Polski Niżowej. PWN. Warszawa, pp. 1-809. (in Polish)

SAŁATA B. 1985. Grzyby (Mycota). Workowce (Ascomycetes). Mączniakowe (Erysiphales). T. 15. PWN. Warszawa, pp. 1-247. (in Polish)

SUCHARZEWSKA E., DYNOWSKA M. 2002. Preliminary evaluation of the effect of Ampelomyces quisqualis on the degree of plant infestations with selected Erysiphales species proposed as potential bioindicators. Plant Protect. Sci. 38 (Special Issue 2): 436-438.

SUNDHEIM L. 1982. Control of cucumber powdery mildew by the hyperparasite Ampelomyces quisqualis and fungicides. Plant. Pathol. 31: 209-214.

SUTTON B.C. 1980. The Coelomycetes. Fungi Imperfecti with pycnidia acervuli and stromata. CMI. Kew Surrey. England.

SZENTIVÀNYI O., KISS L., RUSSELL J.C., KOVÀCS G.M., VARGA K., JANKOVICS T., LESEMANN S., XU X.M., Jeffries P. 2005. Ampelomyces mycoparasites from apple powdery mildew identified as a distinct group based on singlestranded conformation polymorphism analysis of the rDNA ITS region. Mycol. Res. 109 (4): 429-438. 